\title{
Reviving Ophelia with Young Adult Literature
}

We are at a picnic table just an overhand pitch from the ocean, and the sun is shining something fierce. I'm about to give Bobby James a peck on the cheek because I'm feeling so good, when out of the blue he says something funny. As in funny peculiar. Just why did I want to get hitched up with him anyway? he asks. And I can see he doesn't really want the answer, and he's starting to heat up the way he does. What you need to do then is play him out on a long line and wait till he can be reeled back in. But this time he winds up tighter and tighter, and then he just pops me.

And like that, with the back of his hand.

And some voice inside tells me not to cry out, some voice that's been there all the while I guess, just waiting for the right time. (6)

V alerie Hobbs' novel, Letting Go of Bobby James, or How I Found Myself of Steam, is the story of Jody, the young wife of Bobby James Walker, and her struggle to free herself from an abusive relationship. Hobbs is only one of many young adult authors who address the issues identified by Mary Pipher in Reviving Ophelia: Saving the Selves of Adolescent Girls. In her 1994 text Pipher describes the radical changes that occur as girls enter adolescence. As preadolescents they are confident, enthusiastic, and androgynous. But during their teen years, they reject their true selves and become "oversocialized" as they try to meet the expectations of family and peers and to match the media's concept of the feminine role. Pipher uses an allusion to Shakespeare's Ophelia to illustrate her point. A young and confident Ophelia enters adolescence, falls in love with Hamlet, and strives to please both Hamlet and her father. When Hamlet rejects her, her confidence is shattered, and she takes her own life.

Pipher claims that young girls are pressured by society "to split into true and false selves" (22). She identifies three forces at work in their lives: (1) physical and emotional changes, (2) cultural forces including "sexism, lookism, and capitalism" (23), and pressure to become independent of parents. Acknowledging that adolescence has always been a turbulent time for American girls, Pipher claims that girls coming of age in the 1990s must confront many challenges their parents did not experience.

As a psychologist, Pipher supports her claim with vivid case studies illustrating the causes and effects of the oversocialization of girls during adolescence. If girls want to be accepted by their peers, they must deny their true selves and conform to the role society expects and the media perpetuates. She cites families where girls suffer from physical abuse, alcoholic parents, and divorce; schools where girls are treated differently from boys and "lose IQ points as they become feminized" (63); and a society where girls are judged by their appearance, where they are pressured to have sex and to assume the blame when they are raped.

Based upon research in our schools that finds "girls are exposed to almost three times as many boycentered stories as girls-centered stories" (62), Pipher recommends that adolescent girls read more books by and about women, thereby allowing them to identify with protagonists who are struggling with and overcoming the same problems they are confronting in 
their own lives. Her plea has been echoed in two recent texts. Sara Shandler was a high school student when she read Pipher's book and discovered the lives of her friends reflected in it. Hoping to give them an opportunity to share their own stories, she collected essays from her peers, and Ophelia Speaks: Adolescent Girls Write About Their Search for Selves was published in 1999. Like Piper, Shandler believes that young girls need to know they are not alone in their struggles. In 2001, after reading Pipher's book, Cheryl Dellasega, wrote Surviving Ophelia: Mothers Share Their Wisdom in Navigating the Tumultuous Teenage Years. Because her daughter was anorexic, she solicited manuscripts from other mothers whose daughters struggled "more than most during adolescence” (4). Reading their submissions gave her hope; she knew she was not alone. Young adult literature offers an abundance of literature written by talented women who address the very issues that Pipher, Shandler, and Dellasega identify in their textsliterature that describes the lives of young girls struggling with society's expectations while striving to be true to themselves. And, most importantly, this literature portrays them as survivors.

\section{Society's expectations}

The pressures to conform to the expectations of society are vividly illustrated in several young adult novels: Cherie Bennett's Life in the Fat Lane, Laurie Halse Anderson's novel Speak, M. E. Kerr's Deliver Us from Evie, Jacqueline Woodson's I Hadn't Meant to Tell You This, and Valerie Hobbs' Letting Go of Bobby James, or How I Found Myself of Steam are all good examples of novels whose heroines overcome the pressures described by Pipher and survive as independent young women. In Bennett's novel Lara Ardeche, a high school junior and a teen-age beauty queen, is attractive, smart, and talented. Her training for beauty pageants has taught her that "beauty queens are friendly, controlled, sweet, and soft-spoken at all times" (11). Lara's life and sense of self worth revolve around this image of perfectionism. Her mother, a former homecoming queen, maintains her own slim figure by working out continuously and by smoking instead of eating. Her handsome father sees Lara as his little princess. Her circle of friends shares Lara's values. When Pipher describes "bulimic young woman" and "their anorexic sisters," she could be describing Lara Ardeche. According to Pipher they are "oversocialized to the feminine role. They are the ultimate people pleasers. Most are attractive with good social skills. Often they are the cheerleaders and homecoming queens, the straight-A students and pride of their families" (170).

Melinda Sordino, the heroine in Anderson's novel, has broken one of the rules of her peer group; therefore, as she enters ninth grade, she is ostracized by her friends from middle school. As Melinda tells her story, she gradually reveals the details of a party she attended the previous summer. When a handsome senior approached and asked her to dance, she was naïve and flattered. But before she had a chance to say “no," he raped her. Instinctively she called 911; the police arrived and arrested the drunken partygoers while she escaped from the crowd and walked home to an empty house, telling no one of her ordeal. Now Melinda is an outcast. Piper reports on a survey by the American Association of University Women in which one-fourth of high school girls report being cornered and molested (170). When girls report such incidents, their friends blame them for getting the attacker in trouble (233).

In Kerr's novel, Deliver Us from Evie, Evie Burrman is 18 years old and six feet tall. She wears jeans and flannel shirts and smokes, and she can fix any piece of equipment on the family farm. Her younger brother Parr hears jokes about his "brother" Evie. Her mother is disappointed that Evie is not interested in clothes and appearance, while her father appreciates Evie, knowing she is the best worker on his farm. But when Evie and Patsy Duff, the daughter of the local banker, become friends, rumors of homosexuality spread quickly through their small farming community. Piper reports on various cases where girls struggle with a sense of isolation because of their homosexuality. Even when their parents are accepting and understanding, these girls express a need to meet other lesbians and "to read more about girls like me" (111).

Woodson's novel introduces the reader to two protagonists. Marie and Lena build their friendship upon a common bond; they have both lost their mothers. Lena's mother died; Marie's mother abandoned her and her father. Now she has found "a soul mate, another girl floating through this world without 
a mother" (49). There are, however, unwritten rules that separate them. Marie is black, her father is a university teacher; she attends a predominantly black high school where she and her circle of friends set the fashion standards. Lena is poor and shabbily dressed; she is what Marie's father calls "white trash." It eventually become clear that Lena is struggling with a serious problem within her family, one that involves more than the loss of her mother and her life of poverty. When she finally confides in Marie, she insists that Marie tell no one that her father is molesting her. According to Pipher, when a family member commits a sexual assault, it is an injury to everyone in the family (229). Lena's main concern is the protection of her younger sister. She vows to save Dion and pleads with her father to use her and spare her sister.

Jody has been married only thirteen weeks when her husband strikes her, leaving her with a bruised and swollen black eye. There is no apparent reason for his anger, and Jody had thought she knew how to handle him when he started "to heat up" (6). Her first person narrative reveals that she has been raised to believe that pleasing others is important; she claims the best day of her life was "when I won eighth-grade Miss Congeniality and even had a crown” (43). She holds traditional beliefs in regard to marriage: "A good wife would have turned all she had over to her husband, like my mama always did” (16), and, when her Texas driver's license expires, “Bobby James said I wouldn't be needing to drive a whole lot, now that I was a wife” (42). But when he strikes her, she cannot understand because "mostly I tried to keep Bobby James happy” (3). According to Pipher, young girls are "pressured to sacrifice their wholeness in order to be loved. Like Ophelia, all are in danger of drowning” (73).

\section{Conformity}

Each girl faces strong pressure to conform and ostracism when she does not. When Lara (Life in the Fat Lane) is elected Homecoming Queen, her life seems perfect until the unbelievable happens. She begins to gain weight. Despite a vigorous workout schedule and starvation diets, she continues to gain until she weighs over 200 pounds. Lara is eventually diagnosed with Axell-Crowne Syndrome, a condition causing patients to gain weight regardless of the amount of food they eat. Although the doctors offer hope that she may eventually lose all she has gained, Lara must, for now, learn to live as an obese girl in a society that worships thinness and is incredibly cruel to those who do not meet this expectation. All Lara's friends except her boyfriend Jett and best friend Molly abandon her, and she endures the cruel remarks of classmates and strangers.

Melinda (Speak) too is abandoned by her friends from middle school. No one speaks to her in the halls, she has no one to eat lunch with, her books are knocked out of her arms, and, at a pep rally, she is pushed down several rows of bleachers. She makes friends with Heather, who is new to the district, but when Heather is adopted by "the Marthas," a clique of the most popular girls, she abandons Melinda telling her bluntly, "you are the most depressed person I have ever met” (105). Melinda's lips become dry and encrusted as she bites her lips and seals a secret deep inside.

Evie (Deliver Us from Evie) refuses to conform to her mother's expectations of femininity, arguing that "some people like me the way I am" (24). But Patsy Duff's father does not like Evie the way she is and warns her never to come near his daughter again. This discrimination affects not only Evie but the entire Burrman family. Mr. Burrman fears that his mortgage may not be renewed, and Parr, her younger brother, is in danger of losing his girlfriend because of Evie's reputation.

Marie and Lena (I Hadn't Meant to Tell You This), living in a city that is clearly divided between black and white, find themselves caught in the middle. Despite the ridicule of her friends and the loss of her best friend Sherry, Marie refuses to abandon Lena. Even before she knows the source of Lena's sorrow, she wants to "wipe that broken look out of Lena's eyes” (19). When Lena finally confides in her, Marie finds it hard to believe that any father could commit such an act, but, despite her misgivings, Marie is loyal and keeps her promise not to tell.

When Jody (Letting Go of Bobby James, or How I Found Myself of Steam) leaves her husband, she is breaking the rules under which she has been raised. Although divorce may be commonplace in much of American, it is not accepted in the small rural Texas town where she grew up. A letter from her mother assures her that their "Pastor says your place is with 
your husband, Bobby James Walker, and you will come to your senses" (63). Jody constantly questions herself as to why she is no longer with her husband. His sexual appeal is still strong, and she wonders, if she saw him again, would she have the strength to resist.

\section{Parental support}

These heroines receive little or no support from their parents. Piper believes that parents cannot help their children when they themselves are struggling with depression, addiction, and poverty (65). When Lara gains weight, her father is disappointed and no longer calls her by his pet name of "Princess." Her mother is preoccupied in maintaining her own weight and youthful appearance and in trying desperately to retain her husband's affection. Lara's family life eventually shatters when she learns that her father is having an affair with a younger woman. Her mother has no inner core of values and, like Ophelia, tries to commit suicide.

Melinda's parents are busy with their own careers and interests. The family corresponds mainly through notes they leave for each other in the kitchen. When Melinda makes a half-hearted attempt at suicide by scratching her arm with a paper clip, her mother's only response is "I don't have time for this Melinda" (88). But when Melinda's grades fall and she plays hooky, the principal calls a meeting with her parents. They respond in anger, but they have no insight into Melinda's life because she refuses to speak.

Evie's parents are kind and concerned about their children, but they cannot accept what their intuition is telling them-that Evie is gay and in love with Patsy Duff. Her mother blames Patsy for tempting Evie and blames her husband for encouraging Evie to work with him on the farm. Eventually she accepts the fact that Evie is homosexual, but she continues to believe that simply changing Evie's appearance will help to make her life easier, that people will be more accepting of her. When her father finally recognizes the truth, he refuses to speak to Evie, and the tension continues to build between them. Only her younger brother Parr realizes that love happens, that Evie loves Patsy just as he is infatuated with Angel Kidder. Both parents, however, eventually allow their love for Evie to guide them, and the novel ends when Mrs.
Burrman advises Evie and Patsy: “Don't you two be strangers" (148).

Marie has lost not only her mother but also her father who becomes emotionally distant from his daughter as she begins to mature. She longs to be hugged and consoled by him, while Lena is struggling with a situation that Marie finds hard to believe. When Lena's father touches her, her only escape is to picture herself somewhere else, and she willingly sacrifices herself to protect her younger sister, Dion, from her father's abuse. She even defends her father, explaining that she has to love him because he has nothing else left after the death of her mother.

Jody's mother is a weak role model offering no support to a daughter who is struggling to find her independence. Her mother remains in a relationship with a husband who continually abuses and abandons her, only to return and begin the cycle one more time. Jody knows she cannot turn to her mother for advice: "If you have ever looked into the eyes of a hound that's had too many whippings, then you know how it is to look at mama” (53-54). According to Jody's mother, her father was so handsome that she wonders why he ever looked at her. But Jody realizes her mother is afraid to leave him: "By the time Daddy got through with her, she had no self of steam at all" (54). When Bobby James returns to Purley, Texas, Jody’s mother writes to tell her that he has "took up with another woman," (135), one who, like Jody, won the Miss Congeniality contest. This is proof to Jody's mother that Bobby James still loves her daughter, and she advises her that "it's not too late for you to have things the way you want them right here in Purley" (135). Her mother cannot conceive of a life of independence for a woman.

\section{Survival}

These heroines, however, are survivors with the strength to remain true to themselves. Despite pressure from family and peers to focus her life on a perfect appearance and pleasing personality, Lara retains a sense of independence and a personal value system. Bennett skillfully chronicles Lara's changing attitude as she views society from the perspective of a fat girl. Lara begins to realize that she too has held stereotypical opinions about people who are overweight, assuming that they are simply weak and 
undisciplined. When Lara agrees to play a piano solo at the school concert, it is evident that her confidence is slowly being restored.

Like Lara, Melinda is able, over the course of the school year, to find the way to self-acceptance with or without the approval of her peers. As the school year evolves, Melinda begins to show signs that she is "reviving," that she is accepting, not blaming, herself as she takes tentative steps to re-enter the world. She is ready to help not only herself but also her former best friend who is dating Andy Evans, "the beast" who attacked her. Feeling compelled to save Rachel, she warns her and, for the first time, tells someone why she called 911. When Andy, seeking revenge, once again attacks Melinda, this time she "speaks," she screams, she fights back and wins.

Evie and Patsy outwit both sets of parents. Evie resists her mother's attempts to arrange dates with Cord Whittle. She leaves the farm she loves and moves to New York City where she is eventually joined by Patsy. They make a new life for themselves, and it is clear that Evie is at peace with her values and her true identity. The loyalty of Evie and Patsy to each other is a strong contrast to the superficial relationships her brothers have with girls who are pretty but foolish and self-centered.

Marie disregards her father's advice that black people "need to stick together" (69) and his warning that Lena will one day turn on her. She remains a loyal friend to Lena despite her own misgivings. She longs to tell her father what is happening but hesitates for fear of losing Lena's friendship. She wants to tell the police, but Lena refuses all outside help, fearing she will be separated from Dion. But, when her father begins to touch Dion, she rescues the young girl by running away with her. With Lena and Dion safely removed from the scene, Marie feels free to tell their story. She can hear Lena's voice assuring her that "maybe someday other girls like you and me can fly through this stupid world without being afraid" (13).

It is not easy for Jody to leave Bobby James, so she waits in the rest room of the Econo station for him to leave her. While he bangs on the door and threatens that he is "not waiting around all day" (8), she calmly removes her hair rollers and tries to fix her face and blackened eye. Unlike her mother, when Bobby James hits her, she realizes "we have reached some kind of place that we can never go back from" (7). But life on her own is hard. With little money, she sleeps in an unlocked car and in a movie theater before she begins to build a life for herself with a job and new friends. When Bobby James returns, she acknowledges that she still loves him, but she finds the strength to resist. Having assisted in the birth of her friend's baby, she decides "I could be a paramedic, or a nurse, or even a baby doctor" (104). As her story ends, she realizes that "Bobby James was the one who wronged me. He had no right to hit me" (113), and she takes the first step toward her new goal as she pursues her GED.

Pipher cites case studies of girls who are raped and abused and suffer as Melinda and Lena do. Society assumes the victim invited the attack. Girls blame themselves for not stopping the attacker. They are afraid or ashamed to tell what happened. She helps girls like Jody who are seeking their independence, who need to be assured of their self worth. She counsels girls like Lara who are obsessed with weight and appearance, girls who are anorexic and bulimic, who stop making good grades because good grades are not the road to popularity. She advises families like the Burrmans, helping them to accept their daughters and their true identities. All of these heroines survive and fight their way back to selfacceptance. Melinda is able to acknowledge what happened and to realize that she was not to blame. She reclaims her life and values despite the pressures exerted by a peer culture. Jody resists her mother's advice and Bobby James' threats as well as the love she still feels for him. Her experiences have provided the confidence she needs to begin a new and goaloriented life. When Jett returns to Lara, realizing that he still loves her, Lara welcomes him back, but her values have changed. Although she still longs to be thin, her sense of self worth is no longer based solely on appearance. Evie Burrman never falters in her journey to self-acceptance. She loves her family but refuses to be restricted by their community's narrow and restricted beliefs and values. She proclaims her independence and is satisfied with her role in life. Marie remains loyal to Lena. After she disappears from Marie's life, her father, sensing her loneliness, is able to take her face between his hands each morning and ask if she is OK. Perhaps he too has learned Lena's lesson that "We all just people here" (115).

Pipher recommends that girls read books by and about women. Authors such as Bennett, Anderson, 
Kerr, Woodson, and Hobbs not only provide novels by and about women; they also offer role models for girls who face the pressure of growing up in a society that offers little support and acceptance for females who want to remain true to themselves. Lara, Melinda, Evie, Marie, Lena, and Jody illustrate for the reader a path to survival through the turbulent years of adolescence.

Mary Ann Tighe is Professor of English at Troy State University. She is the Director of the program in English Language Arts Education and teaches courses in children's and young adult literature.

\section{Recommended Bibliography}

\section{Novels by Women about Girls Who Survive and Prevail Eating Disorders}

Frank, Lucy. I Am an Artichoke. NY: Bantam Doubleday Dell, 1995. Gottlieb, Lori. Stick Figure: A Diary of My Former Self. NY: Simon \& Schuster, 2000.

Newman, Leslea. Fat Chance. NY: Putnam and Grosset, 1994. Ruckman, Ivy. The Hunger Scream. NY: Walker and Company, 1983.

Woodsen, Jacqueline. Between Madison and Palmetto. NY: Delacorte, 1993.

\section{Physical and Sexual Abuse}

Dessen, Sarah. Dreamland. NY: Viking, 2000.

Efaw, Ann. Battle Dress. NY: Harper Collins, 2000.
Golding, Theresa Martin. The Secret Within. Honesdale, PA: Boyds Mills Press, 2002.

Johnson, Kathleen Jeffrie. The Parallel Universe of Liars. Brookfield, CT: Roaring Brook Press, 2002.

Voight, Cynthia. When She Hollers. NY: Scholastic, 1994.

\section{Homosexuality}

DeGeneres, Betty. Just A Mom. Los Angeles: Advocate Books, 2000.

Greene, Betty. The Drowning of Stephan Jones. NY: Random House, 1997.

McClain, Ellen Jaffee. No Big Deal. NY: Turtleback, 1994.

\section{Self Confidence}

Flake, Sharon G. The Skin I'm In. NY: Jump at the Sun/Hyperion, 1998.

Goobie, Beth. Kicked Out. NY: Orca Publishers, 2002.

Koss, Amy Goldman. The Girls. NY: Dial, 2000.

\section{Works Cited}

Anderson, Laurie Halse. Speak. NY: Farrar Straus Giroux, 1999. Bennett, Cherie. Life in the Fat Lane. NY: Delacorte, 1998.

Dellasega, Cheryl. Surviving Ophelia: Mothers Share Their Wisdom in Navigating the Tumultuous Teenage Years. Cambridge, MA: Perseus, 2001.

Hobbs, Valerie. Letting Go of Bobby James, or How I Found Myself of Steam. NY: Farrar Straus Giroux, 2004.

Kerr, M. E. Deliver Us from Evie. NY: Harper Collins, 1994.

Piper, Mary. Reviving Ophelia: Saving the Selves of Adolescent Girls. NY: Ballatine, 1994.

Shandler, Sara. Ophelia Speaks: Adolescent Girls Write About Their Search for Self. NY: HarperPerenial, 1999.

Woodson, Jacqueline. I Hadn't Meant to Tell You This. NY: Bantam Doubleday Bell, 1994. 